\title{
Biological Effects Due to Hypomagnetic Field and Its Research Progress
}

\author{
Jin-hua Ouyang ${ }^{1}$ \\ Hong-zhen $\mathrm{Li}^{2 \rtimes}$ \\ ${ }^{12}$ College of Physics and Engineering, Qufu Normal University, Qufu, China \\ 'Email: tljssmsm_6889@126.com
}

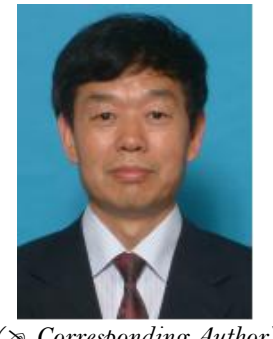

\section{Abstract}

The biological effects due to hypomagnetic field (HMF) is a very important subject for aerospace travelling and space station living, and a large number of studies on the bioeffects of the HMF have been carried out; however, many essential problems, such as physical mechanism, the harmful for human beings and other living organism of the biological effects, are still remaining unknown. In order to promote the solution to these problems, we assembled, classified and analyzed the studies on the biological effects due to the HMF. About one of the essential problem, i.e. the physical mechanism of the biological effects of $\mathrm{HMF}$, we think that the yield $\Phi$ of the singlet spin state of the radical pair theory, that is $\Phi_{s(\theta)}^{0} \approx \frac{1}{2}-\frac{1}{4} \sin ^{2} \theta-\frac{\gamma B_{0}^{2}}{A_{z}^{2}}\left(\frac{3}{4} \sin ^{2} \theta-\sin ^{4} \theta\right)$, is the probable solution, since even the external magnetic field $\boldsymbol{B}_{\mathrm{o}}$ is very weak, the $\boldsymbol{\Phi}_{s(\theta)}^{0}$ is still a monotonous function of $\boldsymbol{\theta}$. About the important research contents in the future, we chose several research hot points by comparing the large quantity of studies.

Keywords: Hypomagnetic field (HMF), Biological effect, Quantum mechanism, Cellular and molecular level, Singlet state yield.

Citation | Jin-hua Ouyang; Hong-zhen Li (2017). Biological Effects Due to Hypomagnetic Field and Its Research Progress. Journal of Life Sciences Research, 4(2): 14-19.

History:

Received: 3 April 2017

Revised: 12 July 2017

Accepted: 15 November 2017

Published: 4 December 2017

Licensed: This work is licensed under a Creative Commons Attribution 3.0 License (cc) Er

Publisher: Asian Online Journal Publishing Group
Contribution/Acknowledgement: The authors are sincerely grateful to Prof. Ying Liu and Dr. Wei-Chuan Mo (State Key Laboratory of Brain and Cognitive Science, Institute of Biophysics, Chinese Academy of Sciences, Beijing, China), as well as to Dr. Bao-Ming Xu (School of Physics, Qufu Normal University, Qufu, China.) for their helpful discussions on this work.

Funding: This work is supported by the Scientific Research Starting Funding: This work is supported by the Scientific Research Starting
Foundation of Qufu Normal University, the "National Science Foundation of Foundation of Qufu Normal University, the "National Science Foundation of
china (Grant No. 11274366)", and the "National Science Foundation of china (Grant No. 51272280)".

Competing Interests: The authors declare that they have no conflict of interests.

Transparency: The authors confirm that the manuscript is an honest, accurate, and transparent account of the study was reported; that no vital features of the study have been omitted; and that any discrepancies from the features of the study have been omittion
study as planned have been explained.

Ethical: This study follows all ethical practices during writing.

\section{Contents}

1. Introduction 15

2. Representative Bioeffects Caused by the HMF 15

3. Studies on the Mechanisms Underlying the Bioeffects of HMF

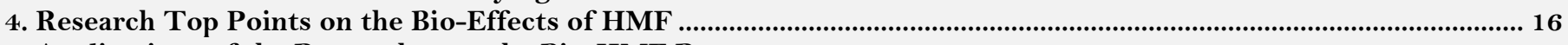

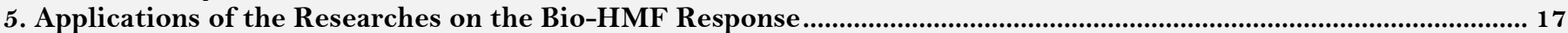

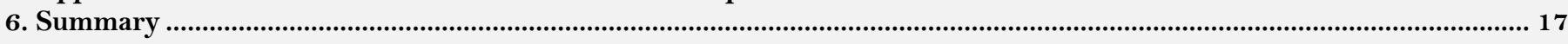

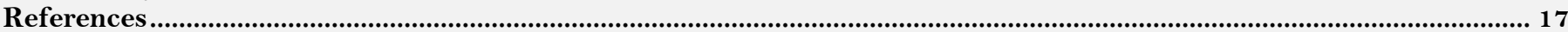




\section{Introduction}

Biological effects due to hypomagnetic field (HMF) regarded as a very important subject originated from the universe exploration, such as aerospace travelling and space station living plan. The Biological effects due to HMF is also often call as bio-HMF response. It is based on the research of static magnetic fields (SMFs). The interaction of SMFs with living organisms has early been become an important subfield [1] many studies on biological effects of SMFs have been carried out [2-4] and the first basic research is that the SMFs are classified as following four grades. (1) the weak grade $(<1 \mathrm{mT}) ;(2)$ the moderate grade $(1 \mathrm{mT}-1 \mathrm{~T}) ;(3)$ the strong grade $(1 \mathrm{~T}-5 \mathrm{~T})$; and $(4)$ the ultrastrong grade $(>5 \mathrm{~T})[1]$. With the research developing of the interaction of SMFs with living organisms, and of the aerospace travelling and space station living plan, the interaction of very weak magnetic field with living organisms has also been become a very important subdiscipline. When the SMF is extremely weak (<5uT), it has a special name, is called a hypomagnetic field (HMF [5]. About the beginning of research on the bio-HMF response, it began to attract attention of the field of space life sciences is at the last years of 1960s, the scientists of USSR made an important contribution to the early research of bio-HMF response [5] and this research filed has been highly regarded in the world since 1980s [5-7]. The presentation order of the contents of this paper is as follows. The representative studies in bio-HMF response are introduced in part 2; studies at several levels for searching the mechanisms underlying the bio-HMF response are introduced in part 3; part 4 is the important hot research points in the future; part 5 is the applications of the researches on the bio-HMF response; and the main contents are summarized in part 6.

\section{Representative Bioeffects Caused by the HMF}

During the evolution process, all living organism experienced the action of the Earth's magnetic field (geomagnetic field, GMF), which is a natural component of their environment [8]. While, Interplanetary space is a natural HMF [5]. Because of the difference on intensity between GMF (35 70uT) and HMF $(<5 \mathrm{uT})[5]$ many effects appear when animals, plants and microorganisms are in the HMF [5]; [7-18]. Among these effects, the special important one is the effect caused by the HMF on locomotion of mammalians. Indeed the HMF is one of the key environment risk factors for astronauts traveling in outer space [19] which has previously been shown to repress locomotion of mammalians [16]. As the locomotion of mammalians is related to not only the motor system, but also nervous system and endocrine system, therefore, in order to find out the origin of repression of locomotion of such systems, it is necessary that the systems must be in a HMF environment [16]. From above, one can see the reason of repression of locomotion is very complicated, because any change of each one system may bring the repression. What is the mechanism underlying so many effects of living organisms in the HMF?

\section{Studies on the Mechanisms Underlying the Bioeffects of HMF}

In order to understand the origin underlying the biological effects, many attempts have been carried out at the cellular level, the molecular level, the further deep quantum mechanics level, and with the synthesis method, the details are as follows.

\subsection{Studies at Cellular Level for Investigating the Mechanism of the Bio-HMF}

At the cellular level, some researches have been reported. The decline of cell viability and mitochondrial activity in mouse skeletal muscle cell in a hypomagnetic field was found [20]. The environment of hypomagnetic field can cause changes in blood leukocytes and plates in mice, which may affect the immune system and characteristics of blood coagulation [21]. The concentration of neutrophil granulocyte was significantly increased after one-month HMF exposure [22]. The continuous HMF exposures can accelerate the proliferation of human neuroblastoma cells by promoting G1-phase progression [23]. A hypomagnetic field can aggravate bone loss induced by hindlimb unloading in rat femurs [24]. A hypomagnetic field of 500nT retarded osteoblast differentiation was showed [25]. A hypomagnetic field can alter action assembly and inhibit cell motility in human neuroblastoma cells [26].

\subsection{Studies at the Molecular Level}

In order to investigate the mechanisms underlying the bio-HMF response, at the molecular level, there is also a number of studies have been carried out. The HMF exposure significantly affected the transcription of gens related to macromolecule transport, metabolic process and mRNA processing, and to the subsequent pathways involved in the organization of the cytoskeleton, regulation of chromatin condensation, transcription, and brain function [27]. Transcript levels of gens that may affect cryptochrome-related hypocotyl growth and flowering in Arabidopsis by a HMF were examined [12]. Several theories have been advanced to describe the effects of hypomagnetic fields [5] $[28,29]$. Among these theories, the radical-pair reaction theory is a leading candidate mechanism to this day. Based on the radical-pair reaction theory, cryptochrome gens (CRYs) have been proposed to be the putative magnetoreceptor genes, which enable an organism to detect magnetic fields [12]; [30, 31]. At the cellular and molecular level, in vitro and in vivo studies have shown that cell cycle progression, tubulin assembly, DNA super condensation and $\mathrm{H}_{2} \mathrm{O}_{2}$ production are potential targets of the $\mathrm{HMF}$ [22]; [31-36].

\subsection{Studies on Change of the Electrical Properties of Biological Tissues Induced By the HMF}

In order to explore the biological effect due to the HMF, many studies on change of the electrical properties of biological tissues induced by the HMF have been carried out. Because the dielectric properties and conductive properties of biological tissues are very important for diagnosing the physiological conditions and for understanding the basic biological processes [37-40] except the studies on these aspects with simulated microgravity method $[37,38]$ these properties of biological tissues (for rat gastrocnemius, whole blood) induced by the HMF have also been carried out [37, 38] and the following important results are found. (1) The conductivity of gastrocnemius increased after four weeks HMF exposure; (2) the image part of the complex conductivity $\varepsilon^{\prime \prime}$, and the image part of the conductivity $\kappa^{\prime \prime}$ are both decreased. (3) Marked increase in permittivity up 
to $19.6 \%$ and conductivity up to $19.1 \%$ were obtained for rat whole blood. (4) The characteristic frequency at which the permittivity and conductivity are increased obviously is $0.1 \mathrm{MHz}$.

\subsection{Studies on Physical Mechanism of the Bio-HMF Response}

Although a large quantity of studies at cellular and molecular level has been carried out, the basic theoretical mechanism is still unknown. How to find the deepest level mechanism underlying the bio-HMF response? Many researchers proceeded the study from investigating the avian navigation [41-47] the most concerned method is the quantum mechanics theory. Its basic thinking is that the physical changes are the base of all changes in living organisms, therefore, in order to exhaust the mechanism of the bio-HMF, it is necessary to study the state change of atomic or electronic particles of the living organism caused by the HMF; One of the frontier theories is the radical-pair (RP) model [48-57] and its basic process is as follows. (1) Propose that a photon excites an electron, and makes the electron transfers from a donor to an acceptor; thus a RP singlet spin state $\mathrm{S}$ can be generated. (2) In the total angular-momentum representation, the vertical component $\mathrm{A}_{\mathrm{z}}$ of the anisotropic hyperfine coupling tensor induces the interconversion between the singlet spin state $\mathrm{S}$ and the triplet spin state $\mathrm{T}_{0}$; the horizontal component $\mathrm{A}_{\mathrm{x}}$ and $\mathrm{A}_{\mathrm{y}}$ induce the transition between the singlet spin state $\mathrm{S}$ and the triplet spin state $T_{+}$and $T_{-}$. (3) The $A_{x}$ and $A_{y}$ can induce the transition between triplet spin state $T_{0}$ and triplet spin state $T_{+}$and $T_{-}$ . (4) The effect of external magnetic field $B$ is its horizontal component $B_{x}$ also can induce the transition between triplet spin state $\mathrm{T}_{0}$ and triplet spin state $\mathrm{T}_{+}$and $\mathrm{T}_{-}$. Thus the external field $\mathrm{B}$ affected the yield of singlet state $\mathrm{S}$, therefore the external $\mathrm{B}$ can be detected $[58,59]$. The relation between yield $\Phi$ of the singlet state $\mathrm{S}$ and the external field $\mathrm{B}_{0}$ and its orientation angle $\theta$ is given as follow [58] $\Phi_{s(\theta)}^{\mathrm{o}} \approx \frac{1}{2}-\frac{1}{4} \sin ^{2} \theta-\frac{\gamma B_{0}^{2}}{A_{z}^{2}}\left(\frac{3}{4} \sin ^{2} \theta-\sin ^{4} \theta\right)$

Where $\Phi_{s(\theta)}^{0}$ is the singlet yield; $A_{z}$ is the vertical hyperfine coupling component; $\gamma=\frac{1}{2} \mu_{B} g_{s}$ is the gyromagnetic ratio, with $\mu_{B}$ the Bohr magneton and $g_{s}$ the $g$ factor of the electron, here $g_{s}=2 ; B_{0}$ is the intensity of the Earth's magnetic field (namely the external field), and $\theta$ describes the orientation angle of the $B_{0}[59]$. The last term is the second-order perturbation and $1 / 2-\sin ^{2} \theta / 4$ in Eq. (1) plays a significant role in the singlet yield $\Phi_{s(\theta)}^{0}[58]$. Notably, even when the local field is very weak, i.e., the value of $B_{0}$ is very small, Eq. (1) is still a monotonous function of $\theta$ [59]. When $B_{0}$ is smaller than 5uT, is Eq. (1) still true? It may be one quantum mechanism of the bio-HMF response, however there is no affirmative answer at present; it need a lot of experimental and theoretical studies.

Binhi VN proposed one different physical mechanism based on classical precessional dynamics of a magnetic moment in a thermally disturbed environment and includes a minimum of necessary parameters-the gyromagnetic ratio, thermal relaxation time, and rate of downstream events generated by changes in the state of the magnetic moment $[39,40]$.

\section{Research Top Points on the Bio-Effects of HMF}

Although many researches on biological effects due to HMF have been done as described above, to solve thoroughly the mechanism underlying biological effects due to the HMF, it is necessary to investigate in many aspects. By comparing the large quantity of completed research works, we think that the following questions maybe the research top points.

\subsection{What is the Clear and Precise Reason and what is the Whole Course of Repression of Locomotion of Mammalians?}

It was proposed earlier that mitochondria are the organelle most sensitive to changes in environmental magnetic field [8]; [20]. HMF exposure reduces viability, energy production and mitochondrial activity of primary mouse skeletal muscle cells [20]. Mitochondrion can respond to HMF directly, and thus HMF-induced decline in cell functionally may result from reduction in energy production and mitochondrial activity [20]. Negative effects of HMF on skeletal muscle cells probably contribute to HMF-induced repression on locomotion in mammalians [20]. Can the experimental result on mitochondrion appear in other cells? A HMF can influence the different cells in different systems [20-26]. Which system is the first one affected by the HMF if the different systems' response to HMF is not simultaneous when a living organism is in a HMF? And do the systems have interaction when mammalians are in a HMF? Cryptochromes gens (CRYs) have been proposed to be the putative magnetoreceptor genes, which enable an organism to detect magnetic fields [12]; [30, 31]. The results of the research suggest the involvement of the cryptochromes in mediating the HMF effects [19]. But how do the cryptochromes involve in the course? Can the experimental results in human neuroblastoma cells in the hypomagnetic field [19] appear in other cells? Detailed structural and biochemical analysis of CRY proteins would elucidate how they may respond to changes in the magnetic environment [19] and that the further researches are needed to elucidate the reason and the course of repression of locomotion of mammalians.

\subsection{Is the Bio-HMF Response a General Law in Living Organisms?}

Although many effects appear when animals, plants and microorganisms are in a HMF, the answer is not sure because of limited researches. From the evolutionary theory, the answer may be sure, because all living organisms on the Earth have been exposed to the geomagnetic field (GMF), a natural component of the habitability environment, through the evolutionary history. In evolution, all living organisms have built their mechanisms to adapt the environment. When the environment changes, that is to say, when intensity of the magnetic field from that of the GMF to the HMF, living organisms may be surely have response accordingly. 


\subsection{What's The Relationship between the Quantum Mechanism and the Mechanism of Electromagnetics on the Bio-HMF Response?}

The rat whole blood's electromagnetic parameters were affected by the HMF [37, 38].If Eq (1) is one quantum mechanism of the bio-HMF response, what's the relationship between the quantum mechanism and the mechanism of electromagnetics? That's to say, can a function of electromagnetic parameters related a HMF and based on Eq (1)be derived?

\subsection{Can the Pure Bio-HMF Response be Gotten?}

Bio-HMF response may be related with ambient alternating magnetic fields [5, 60] since in the experiments on a HMF, the alternating ambient magnetic fields is always present because of the magnetic and/or electric properties of the measuring instrument [20, 26]. The results on the experiments may be the comprehensive effects with a HMF and an alternating magnetic field. Therefore, the effects of ambient magnetic field HMF should be discriminated by using advanced experimental design in future experiments.

Beside those, there are some other questions, such as: although there are bio-HMF responses in molecular level $[12,27]$ can the biological effects be inherited? The cell with mitochondria can have bio-HMF response [20] and the cell without mitochondria just like red blood cell(RBC)can have no bio-HMF response [21] so what are the mechanisms of the results in cellular level? And are the mechanisms are general? If the mechanisms are general in bio-HMF responses, are they still true in biological effects due to magnetic fields except for HMF? The HMF can alter development of xenopus embryos [17] and it suggests the HMF can affect the cell communication, what are the mechanisms in molecular level underlying the two results and have the mechanisms intrinsic relationship with bio-HMF response in the cell with mitochondria [20] ? Therefore, there will much work to be done to elucidate the bio-HMF response. To do those works in the future is very valuable.

\section{Applications of the Researches on the Bio-HMF Response}

Since many effects appear when animals, plants and microorganisms are in the HMF [5]; [7-18] therefore, it is needless to say that the researches on the bioeffects of HMF will have many important applications, and the followings are considered as important possible applications at the present.

(1) HMF is one of the key environment risk factors for astronauts traveling in outer space, and the outer space living [19] (2) the further investigation of HMF effects would benefit the development of the

health care strategy for the astronauts in the space mission [18] (3) to elucidate bio-HMF response may help to solve the mechanism for organisms to sense GMF [26] (4) stem cell culturing in the HMF, such a physical approach which stimulate the growth of neural progenitor/stem cells non-invasively, has great potency for clinical application in stem cell therapy [61] (5) the research on bioeffects of HMF is also important to protect the workers in the HMF on the Earth [5,62]. With the development on the research of bio-HMF response, more and more uses will be found.

\section{Summary}

The micro mechanism underlying the biological effects due to the HMF is the key problem of the biomagnetics, and there has been no answer. By analyzing the radical pair magnetoreception model,

We think that the yield $\Phi$ of the singlet state, $\Phi_{s(\theta)}^{\mathrm{o}} \approx \frac{1}{2}-\frac{1}{4} \sin ^{2} \theta-\frac{\gamma B_{0}^{2}}{A_{z}^{2}}\left(\frac{3}{4} \sin ^{2} \theta-\sin ^{4} \theta\right)$ is the probable solution, since even the external magnetic field $\boldsymbol{B}_{0}$ is very weak, the $\Phi_{s(\theta)}^{0}$ is still a monotonous function of $\boldsymbol{\theta}$. About the important research contents in the future, we chose several research hot points by comparing the large quantity of studies. The representative Bioeffects caused by the HMF; studies at the cellular level, the molecular level, and with the synthesis method are introduced; and the applications of the researches on the bioeffects of HMF are also introduced.

\section{References}

[1] S. Ghodbane, A. Lahbib, M. Sakly, and H. Abdelmelek, "Bioeffects of static magnetic fields: Oxidative stress, Genotoxic effects, and cancer studies," BioMed Research International, vol. 2013, pp. 1-12, 2013. View at Google Scholar | View at Publisher

L. Baghel, S. Kataria, and K. N. Guruprasad, "Static magnetic field treatment of seeds improves carbon and nitrogen metabolism under salinity stress in soybean," Bioelectromagnetics, vol. 37, pp. 455-470, 2016. View at Google Scholar | View at Publisher

[3] M. Aydin, M. S. Taspinar, Z. E. Cakmak, R. Dumlupinar, and G. Agar, "Static magnetic field induced epigenetic changes in wheat callus," Bioelectromagnetics, vol. 37, pp. 504-511, 2016. View at Google Scholar | View at Publisher

[4] M. N. Zhadin, "Review of Russian literature on biological action of DC and low-frequency AC magnetic fields," Bioelectromagnetics, vol. 22, pp. 27-45, 2001. View at Google Scholar

[5] W. C. Mo, Y. Liu, and R. Q. He, "A biological perspective of the hypomagnetic field from definition towards mechanism," Prog Boochem Biophys, vol. 39, pp. 835-842, 2012. View at Google Scholar

G. D. Li, Biomagnetics: Application. Beijing: Science Press, 1983.

J. C. Jiang, X. B. Wang, M. L. Xu, B. Li, W. H. Yang, D. X. Zhao, and T. Song, "An Experimental system for research biological effects of hypomagnetic field space," Acta Biophysica Sinica, vol. 19, pp. 218-22 1, 2003. View at Google Scholar

[8] N. A. Belyavskaya, "Biological effects due to weak magnetic field on plants," Advances in Space Research, vol. 34, pp. 1566-1574, 2004. View at Google Scholar | View at Publisher

[9] B. Jia and P. Shang, "Research progress of biological effects of hypomagnetic fields," Space Medicine E Medical Engineering, vol. 22, pp. 308-312, 2009. View at Google Scholar

[10] W. C. Mo, Z. J. Zhang, Y. Liu, G. J. Zhai, Y. D. Jiang, and R. Q. He, "Effects of a hypogeomagnetic field on gravitropism and germination in soybean," Advances in Space Research, vol. 47, pp. 1616-162 1, 2011. View at Google Scholar | View at Publisher

[11] G. J. Wan, S. L. Jiang, Z. C. Zhao, J. J. Xu , X. R. Tao, G. A. Sword, Y. B. Gao, W. D. Pan , and F. J. Chen "Bio-effects of near-zero magnetic fields on the growth, development and reproduction of small brown planthopper, laodelphax striatellus and brown planthopper, nilaparvata lugens," Journal of Insect Physiology, vol. 68, pp. 7-15, 2014. View at Google Scholar | View at Publisher

[12] C. X. Xu, X. Yin, Y. Lv, C. Z. Wu, Y. X. Zhang, and T. Song, "A near-null magnetic field affects CRY-related hypocotyl growth and flowering in arabidopsis," Advances in Space Research, vol. 49, pp. 834-840, 2012. View at Google Scholar |View at Publisher

[13] C. X. Xu, S. F. Wei, Y. Lu, Y. X. Zhang, C. F. Chen, and T. Song, "Removal of the local geomagnetic field affects reproductive growth in arabidopsis," Bioelectromagnetics, vol. 34, pp. 437-442, 2013. View at Google Scholar | View at Publisher 
[14] C. X. Xu, Y. Lv, C. F. Chen, Y. X. Zhang, and S. F. Wei, "Blue light-dependent phosphorylations of CRYs are affected by magnetic fields in arabidopsis," Advances in Space Research, vol. 53, pp. 1118-1124, 2014. View at Google Scholar |View at Publisher

[15] C. X. Xu, Y. Li, Y. Yu, Y. X. Zhang, and S. F. Wei, "Suppression of arabidopsis flowering by near-null magnetic fields affected by light," Bioelectromagnetics, vol. 36, pp. 476-479, 2015. View at Google Scholar | View at Publisher

[16] J. P. Fu, W. C. Mo, Y. Liu, and R. Q. He, "Bioeffects and mechanisms of hypomagnetic fields on locomotion of mammalians," China Aerospace Institute and China's Space Law Institute Academic Essays, vol. 2014, pp. 707-713, 2014.

[17] W. C. Mo, Y. Liu, H. M. Cooper, and R. Q. He, "Altered development of xenopus embryos in a hypogeomagnetic field," Bioelectromagnetics, vol. 33, pp. 238-246, 2012. View at Google Scholar | View at Publisher

[18] W. C. Mo, J. Fu, H. M. Ding, Y. Liu, H. Qian, and R. Q. He, "Hypomagnetic field alters circadian rhythm and increases algesia in adult male mice," Progress in Biophysics and Molecular Biology, vol. 42, pp. 639-646, 2015. View at Google Scholar

[19] W. C. Mo, Y. Liu, and R. Q. He, "Hypomagnetic field, an Ignorable environmental factor in space?," Science China Life Sciences, vol. 57, pp. 726-728, 2014. View at Google Scholar |View at Publisher

[20] J. P. Fu, W. C. Mo, Y. Liu, and R. Q. He, "Decline of cell viability and mitochondrial activity in mouse skeletal muscle cell in a hypomagnetic field," Bioelectromagnetics, vol. 37, pp. 212-222, 2016. View at Google Scholar | View at Publisher

[21] B. Jia, W. J. Zhang, L. Xie, Q. Zhang, Z. H. Tian, A. R. Qian, and P. Shang, "Effects of hypomagnetic field environment on hematopoietic system in mice," Space Medicine EMedical Engineering, vol. 24, pp. 318-322, 2011. View at Google Scholar

[22] H. M. Ding, W. C. Mo, J. P. Fu, J. H. Hu, Y. Liu, and Q. Hua, "The hematopoietic system responses to one-month continuous hypomagnetic field exposure in adult mice," Progress in Modern Biomedicine, vol. 14, pp. 5001-5004, 2014. View at Google Scholar

[23] W. C. Mo, Z. J. Zhang, Y. Liu, P. F. Bartlett, and R. Q. He, "Magnetic shielding accelerates the proliferation of human neuroblastoma cell by promoting G1-phase progression," Plos One, vol. 8, p. e54775, 2013. View at Google Scholar |View at Publisher

[24] B. Jia, L. Xie, Q. Zheng, P. F. Yang, W. J. Zhang, C. Ding, A. R. Qian, and P. Shang, "A Hypomagnetic field aggravates bone loss induced by hindlimb unloading in rat femurs," Plos One, vol. 9, p. e 105604, 2014. View at Google Scholar | View at Publisher

[25] J. Zhang, C. Ding, and P. Shang, "Alterations of mineral elements in osteoblast during differentiation under hypo, moderate and high static magnetic fields," Biological Trace Element Research, vol. 162, pp. 153-157, 2014. View at Google Scholar | View at Publisher

[26] W. C. Mo, Z. J. Zhang, D. L. Wang, Y. Liu, P. F. Bartlett, and R. Q. He, "Shielding of the geomagnetic field alters action as sembly and inhibits cell motility in human neuroblastoma cells," Scientific Reports, vol. 6, pp. 1-15, 2016. View at Google Scholar

[27] W. C. MO, Y. Liu, P. F. Bartlett, and R. Q. He "Transcriptome profile of human neuroblastoma cells in the hypomagnetic field," Science China Life Sciences, vol. 57, pp. 448-461, 2014. View at Google Scholar | View at Publisher

[28] F. S. Barnes and B. Greenebaum, "The effects of weak magnetic fields on radical Pairs," Bioelectromagnetics, vol. 36, pp. 45-54, 2015. View at Google Scholar

[29] F. S. Prato, "Non-thermal extremely low frequency magnetic field effects on opioid related behaviors: Snails to humans, mechanisms to therapy," Bioelectromagnetics, vol. 36, pp. 333-348, 2015. View at Google Scholar | View at Publisher

[30] L. E. Foley, R. J. Gegear, and S. M. Reppert, "Human cryptochrome exhibits light dependent magnetosensitivity," Macmillan Publishers Limited Nat Commun, vol. 2, pp. 1-3, 2011. View at Google Scholar

[31] K. Maeda, A. J. Robinson, K. B. Henbest, H. J. Hogben, T. Biskup, M. Ahmad, E. Schleicher, S. Weber, C. R. Timmel, and P. J. Hore, "Magnetically sensitive light-induced reactions in cryptochrome are consistent with its proposed role as a magnetoreceptor," Proceedings of the National Academy of Sciences, vol. 109, pp. 4774-4779, 2012.

[32] D. L. Wang, X. S. Wang, R. Xiao, Y. Liu, and R. Q. He, "Tubulin assembly is disordered in a hypogeomagnetic field," Biochemical and Biophysical Research Communications, vol. 376, pp. 363-368, 2008. View at Google Scholar | View at Publisher

[33] C. F. Martino, L. Portelli, K. McCabe, M. Hernandez, and F. Barnes, "Reduction of the earth's magnetic field Inhibits growth rates of model cancer cell lines," Bioelectromagnetics, vol. 31, pp. 649-655, 2010. View at Google Scholar |View at Publisher

[34] C. F. Martino, H. Perea, U. Hopfner, V. L. Ferguson, and E. Wintermantel, "Effects of weak static magnetic fields on endothel ial cells," Bioelectromagnetics, vol. 31, pp. 296-301, 2010. View at Google Scholar

[35] I. Y. Belyaev, Y. D. Alipov, and M. Harms-Ringdahl, "Effects of zero magnetic field on the conformation of chromatin in human cells," Biochimica et Biophysica Acta (BBA)-General Subjects, vol. 1336, pp. 465-473, 1997. View at Google Scholar | View at Publisher

[36] C. F. Martino and P. R. Castello, "Modulation of hydrogen peroxide production in cellular systems by low level magnetic fields," Plos One, vol. 6, p. e22753, 2011. View at Google Scholar | View at Publisher

[37] C. Ding, B. Jia, X. Liu, Y. Lv, J. Wang, and P. Shang, "Effects of hypo-magnetic field and simulated microgravity on dielectric properties of gastrocnemius in rats," Space Medicine $\mathscr{E}^{2}$ Medical Engineering, vol. 27, pp. 1-5, 2014.

[38] C. Ding , B. Jia, X. Liu, Y. Lv , J. Wang, and P. Shang "Dielectric properties of rat whole blood, spleen and testis were changed by hypo-magnetic field and hind-limb unloading," Space Medicine ङ Medical Engineering, vol. 27, pp. 157-163, 2014.

[39] V. N. Binhi, "A primary physical mechanism of the biological effects of weak magnetic fields," Biophysics, vol. 61, pp. 170-176, 2016. View at Google Scholar | View at Publisher

[40] V. N. Binhi and F. S. Prato, "A physical mechanism of magnetoreception: Extension and analysis," Bioelectromagnetics, vol. 38, pp. 41-52, 2017. View at Google Scholar | View at Publisher

[41] S. Johnsen and K. T. L. Omann, "Magnetoreception in animals," Physics Today, pp. 29-35, 2008. View at Google Scholar

[42] T. Ritz, "Quantum effects in biology: Bird navigation," Procedia Chemistry, vol. 3, pp. 262-275, 2011. View at Google Scholar |View at R. Wiltschko and W. Wiltschko, "Magnetoreception," Bio Essays, vol. 28, pp. 157-168 2006. View at Google Scholar

$[43]$ R. Wiltschko and W. Wiltschko, "Magnetoreception," Bio Essays, vol. 28, pp. 157-168 2006. View at Google Scholar
[44] J. Z. B. M. Xu, "Dark state population determines magnetic sensitivity in radical pair magnetoreception model," Scientific Reports, vol. 6 , pp. 1-9, 2016.

[45] J. M. Cai, F. Caruso, and M. B. Plenio, "Quantum limits for the magnetic sensitivity of chemical compass," Physical Review A, vol. 85, p. 040304, 2012. View at Google Scholar | View at Publisher

[46] Y. T. Zhang, G. P. Berman, and S. Kais, "Sensitivity and entanglement in the avian chemical compass," Physical Review E, vol. 90, p. 042707, 2014. View at Google Scholar | View at Publisher

[47] J. M. Cai and M. B. Plenio, "Chemical compass model for avian magnetoreception as a quantum coherent device," Physical Revierw Letters, vol. 111, p. 230503, 2013. View at Google Scholar | View at Publisher

[48] S. Y. Qin, H. Yin, C. L. Yang, Y. F. Dou, Z. Liu, P. Zhang, H. Yu, Y. L. Huang, J. Feng, J. F. Hao, J. Hao, L. Z. Deng, X. Y. Yan, X. L. Dong, Z. X. Zhao, T. Jiang, H. W. Wang, S. J. Luo, and C. Xie, "A magnetic protein biocompass," Nature Materials, vol. 15, pp. 217-226, 2016. View at Publisher

[49] P. J. Hore and H. Mouritsen, "The radical-pair mechanism of magnetoreception," Annual Review of Biophysics, vol. 45, pp. 299-344, 2016. View at Google Scholar | View at Publisher

[50] T. Ritz, S. Adem, and K. Schulen, "A model for photoreceptor-based magnetoreception in birds," Biophysical Journal, vol. 78, pp. 707-7 18, 2000. View at Google Scholar | View at Publisher

[51] C. Nießner, S. Denzau, E. P. Malkemper, J. C. Gross, H. Burda, M. Winklhofer, and L. Peichl, "Cryptochrome 1 In retinal cone photoreceptors suggests a novel function role in mammals," Scientific Reports, vol. 6, pp. 1-7, 2016.

[52] P. Bolte, F. Bleibaum, A. Einwich, A. Günther, M. Liedvogel, D. Heyers, A. Depping, L. Wöhlbrand, R. Rabus, U. J. Bienhold, and H. Mouritsen, "Localisation of the putative magnetoreceptive protein cryptochrome $1 \mathrm{~b}$ In the retinae of migratory birds and homing pigeons," Plos One, vol. 1 1, pp. 1-17, e0147819, 2016. View at Google Scholar | View at Publisher

[53] X. L. Zhu and J. Y. Wang, "The effect of geomagnetism on biomagnetism," Chinese Journal of Nature, vol. 35, pp. $200-206,2013$.

[54] B. F. Zhang and L. X. Tian, "Progress in the mechanisms of animal geomagnetic navigation," Chinese Journal of Zoology, vol. 50, pp. 801-819, 2015 .

[55] D. R. Kattnig, I. A. Solov'yov, and P. J. Hore, "Electron spin relaxation in cryptochrome-based magnetoreception," Physical Chemistry Chemical Physics, vol. 18, pp. 12443-12456, 2016. View at Google Scholar | View at Publisher

[56] R. Wiltschko, M. Ahmad, C. NieBer, D. Gehring, and W. Wiltschko, "Light-dependent magnetoreception in birds: The crucial step occurs in the dark," Journal of The Royal Society Interface, vol. 13, p. 20151010, 2016. View at Google Scholar | View at Publisher 
[57] S. Schwarze, N.-L. Schneider, T. Reichl, D. Dreyer, N. Lefeldt, S. Engels, N. Baker, P. J.Hore, and H. Mouritsen, "Weak broadband electromagnetic fields are more disruptive to magnetic compass orientation in a night-migratory songbird (Erithacus Rubecula) than strong narrow-band fields," Frontiers in Behavioral Neuroscience, vol. 10, pp. 1-13, 2016. View at Google Scholar |View at Publisher

[58] B. M. Xu, J. Zou, H. Li, J. H. Li, and B. Shao, "Effect of radio frequency fields on the radical pairagnetoreception model," Physical Review E vol. 90, p. 042711, 2014. View at Google Scholar|View at Publisher

[59] B. M. Xu, J. Zou, J. G. Li, and B. Shao, "Estimating the hyperfine coupling parameters of the avian compass by comprehensively considering the available experiment results," Physical Review E, vol. 88, p. 032703, 2013. View at Google Scholar | View at Publisher

[60] E. Choleris, C. Del Seppia, A. W. Thomas, P. Luschi, S. Ghione, G. R. Moran, and F. S. Prato "Shielding, but not zeroing of the ambient magnetic field reduces stress-induced analgesia in mice," Proceedings of Biological Sciences, vol. 269, pp. 193-201, 2002. [61] J. P. Fu, W. C. Mo, Y. Liu, P. F. Bartlett, and R. Q. He, "Elimination of the geomagnetic field stimulates the proliferation of mouse
neural progenitor and stem cells," Protein Cell, vol. 7, pp. 624-637, 2016. View at Google Scholar | View at Publisher

[62] S. A. Gudoshnikov, S. N. Venediktov, Y. B. Grebenshchikov, P. A. Kuznetsov, S. A. Manninen, O. N. Krivolapova, K. A. Trukhanov, O. S. Kruglov, and A. V. Spasskii, "A screening chamber for attenuating the earth's magnetic field based on roll magnetic materials," Measurement Techniques, vol. 55, pp. 329-335, 2012. View at Google Scholar | View at Publisher 